\title{
A Teopoética em Rubem Alves
}

\author{
Luana Martins Golin*
}

\section{Resumo}

A religião se expressa por meio da linguagem, das narrativas, dos mitos, da poesia. É por intermédio da linguagem que é possível ao ser humano articular suas identidades, crenças e compreensão de mundo. Mais do que dados estatísticos e análises sociais, a religião é um complexo fenômeno da linguagem humana. Nessa direção, Rubem Alves (1933-2014) torna-se um interlocutor fundamental para se pensar uma poética da religião. O caminho percorrido por ele foi o da teopoética, uma tentativa de "desengaiolar" e libertar as palavras das prisões dos dogmas, dos sentidos e da univocidade. Seus textos saborosos podem ser degustados, em uma dinâmica que une a ficção, o prazer e a reflexão. Nesse movimento ou dança das palavras, Deus ou o Sagrado se manifesta-se em atos de criação, como poeta. Para compor este artigo, foram utilizadas como base as seguintes obras, em ordem de publicação no Brasil: Lições de Feitiçaria: meditações sobre a poesia (2003); Variações sobre o prazer (2014) e Rubem Alves essencial: 300 pílulas de sabedoria (2015). Trata-se da fase mais tardia do escritor, em que predomina uma linguagem mais literária e narrativa.

Palavras-chave: Rubem Alves. Teopoética. Religião. Palavra. Beleza.

\section{Rubem Alves Theopoetics}

\begin{abstract}
Religion is expressed by language, narratives, myths, poetry. The human being can articulate by the language his identities, beliefs, and world view. Religion is more than statical data, and social analysis, but a complex phenomenon of human language. Thus Rubem Alves (1933-2014) is a fundamental interlocutor to think a poetics of religion. He used theopoetics to unleash and set free the words from the prisons of dogmas, senses, and oneness. His tasty texts can be experienced in a mix of fiction, pleasure,

* Universidade Metodista de São Paulo - UMESP. A autora é teóloga, mestra e doutora em Ciências da Religião pela Universidade Metodista de São Paulo, onde atua como professora na Faculdade de Teologia, na modalidade EAD e Lato Sensu. Currículo lattes: http://lattes.cnpq.br/3559845486973101. E-mail para contato: luanamgolin@ gmail.com.br
\end{abstract}


and thinking. God and Sacred are manifested as poets in creation acts in a movement or dance of words. The following works were used to compose this article - in order of publication in Brazil: Lições de Feitiçaria: meditações sobre a poesia (2003); Variações sobre o prazer (2014) e Rubem Alves essencial: 300 pílulas de sabedoria (2015). These works belong to a later phase of the writer, marked by a more literary and narrative language.

Key-words: Rubem Alves. Theopoetics. Religion. Word. Beauty.

\section{La Teopoética en Rubem Alves}

\section{Resumen}

La religión se expresa por medio del lenguaje, de las narraciones, de los mitos, de la poesía. Por medio del lenguaje el ser humano puede articular sus identidades, creencias y comprensión del mundo. Más que datos estadísticos y análisis sociales la religión es un complejo fenómeno de lenguaje humana. En esa dirección, Rubem Alves (19332014) se convierte en interlocutor fundamental para pensar una poética de la religión. El camino que él recorrió fue el de la teopoética, un intento de desenjaular y libertar las palabras de las prisiones de los dogmas, de los sentidos y de la univocidad. Sus textos sabrosos pueden ser degustados, en una dinámica que une la ficción, el placer, y la reflexión. En ese movimiento o danza de las palabras, Dios o lo sagrado se manifiesta en actos de creación, como poeta. Para este artículo se utilizaron como base las siguientes obras, en orden de publicación en Brasil: Lições de Feitiçaria: meditacõoes sobre a poesia (2003); Variações sobre o praz̧er (2014) e Rubem Alves essencial: 300 pílulas de sabedoria (2015). Se trata del período más tardío del escritor, en el que predomina un lenguaje más literario y narrativo.

Palabras clave: Rubem Alves. Teopoética. Religión. Palabra. Belleza.

\section{Introdução}

Para pensar sobre Deus não leio os teólogos, leio os poetas. - Rubem Alves

Deus-Poietés, Deus que cria mediante a palavra, verbo em movimento que gera existência ao inexistente. Encontros de beleza, poesia e vida. Há algo em comum entre o poeta e Deus, ou algo divino no poeta.

A proposta deste artigo é apresentar alguns temas concernentes à linguagem e à poesia que sugerem uma poética de Deus, ou teopoética, a partir de Rubem Alves. Pretende-se percorrer a seguinte travessia: 1) A primeira seção revela o valor da palavra criadora, como um feitiço ou magia. 2) A segunda seção é dedicada ao tema da eucaristia como presença e teofagia. 3) A última seção consiste em uma reflexão acerca da beleza, numa perspectiva estético-teológica e estético-poética. 
As obras de Rubem Alves utilizadas compreendem o seu período mais tardio, no qual ele escreve de maneira mais ensaística e literária, não se restringindo ao universo acadêmico.

\title{
1. A palavra criadora - o feitiço da poesia
}

\author{
"No principio é a Palavra..." Feitiçaria é o mundo onde \\ as palavras têm poder. O feiticeiro fala e a palavra, sem o \\ auxílio das mãos, realiza o que diz. Deus diz "Paraíso!", e um \\ jardim de delícias aparece. A bruxa diz. "Sapo!", \\ e o príncipe se transforma em sapo. \\ - Rubem Alves
}

Os poetas sempre reconheceram que poesia e magia são irmãs gêmeas. - Rubem Alves

O foco desta seção é explorar um pouco mais o uso poético da linguagem, a partir de Rubem Alves. Outros autores, como o crítico literário canadense Northrop Frye (2004), classificaram a palavra como mágica criadora, colocando-a como a primeira fase da linguagem humana. Rubem Alves tinha uma compreensão semelhante ao que Frye descreve como o uso poético da linguagem.

Essa primeira fase é marcada por uma espécie de magia ou feitiço, pois as palavras têm poder. Pela palavra é possível criar, curar e trazer à presença: "Toda poesia é um ato de feitiçaria cujo objetivo é tornar presente e real aquilo que está ausente e não tem realidade" (ALVES, 2015, p. 227). Muitos teólogos e filósofos acreditam que magia é superstição, pois as palavras são apenas instrumentos da razão para serem utilizadas. Não entendem que magia é criar pelo poder da palavra. A atitude de um poeta é semelhante à atitude de um mago.

Nesta primeira fase, existe certa concretude e não há abstração conceitual. A linguagem é polissêmica, conotativa, metafórica, literária e poética. A linguagem da imanência se encontra na metáfora. Em Gênesis 1, há referências à fase metafórica, pois a palavra foi o agente de criação que levou "a coisa a ser”. Das palavras escorrem substâncias/coisas... Para a visão bíblica, as palavras são o fundamento da realidade, pois Deus criou o mundo com palavras. A citação a seguir exemplifica essa materialidade da linguagem: 
O sentido antigo das palavras, em especial no teatro trágico, tinha uma aura e um efeito materiais ausentes da epistemologia moderna. Uma profecia, um dito oracular, uma fórmula de anátema na tragédia grega carregavam consigo uma fatalidade literal. A linguagem não representava ou descrevia o fato: ela era o fato (STEINER, 2005, p. 348; grifos do autor).

Nesse primeiro momento, predomina a concretude da lógica metafórica. Por esse motivo, há certa debilidade junto ao pensamento abstrato moderno.

Rubem Alves (2003) expressou o valor da palavra poética como responsável pela criação de mundos. A palavra é como um feitiço. Ao ser lançada, algo ocorre. Aquilo a que damos o nome de "realidade" é, nessa perspectiva, feitiço. A palavra é viva, mas pode ser muito perigosa ou enganosa. Uma única palavra pode conter o todo: "Na literatura, frequentemente o curto é muito maior que o comprido. Há poemas que contêm um universo" (ALVES, 2015, p. 118).

Ao longo do tempo, a linguagem reconfigura-se e adquire novos contornos. Num segundo momento, a linguagem torna-se mais abstrata e metonímica. Pode-se dizer que a linguagem sacramental ou dogmática é fruto dessa segunda fase:

Muito das doutrinas centrais da tradição só podem ser gramaticalmente expressas na forma de metáforas. Assim: Cristo " $e$ ” Deus e homem; na Trindade três pessoas "são" uma; na Presença Real o corpo e o sangue "são" o pão e o vinho. Ao serem racionalizadas as doutrinas (...) a metáfora é traduzida em linguagem metonímica e assim é "explicada" (FRYE, 2004, p. 82; grifos do autor).

Essa citação revela a transição, no âmbito da religião cristã, da primeira para a segunda fase da linguagem.

Em outra perspectiva cristã, com destaque para o cristianismo oriental, há a tradição da teologia mística, também conhecida como teologia negativa ou apofática. Do grego, apophatikós = negativo, derivado do verbo apóphami, que significa "dizer não, negar". Para a teologia apofática, o conhecimento de Deus só é possível afirmando-se o que Ele não é. O conhecimento apofático é contrário ao conhecimento catafático (do grego kataphatikós = afirmativo ou enfático), o qual define Deus por afirmações positivas. A teologia mística ou negativa ressalta a inadequação da analogia e os limites da linguagem na tentativa de definir Deus: "Para eles nenhuma palavra - como, por exemplo, "Ser" - é aplicável a Deus, porque palavras são finitas e Deus não o é: o ver- 
dadeiro Deus está 'escondido', além de todo o pensamento, e a fortiori além das palavras" (FRYE, 2004, p. 35).

Rubem Alves concorda que a linguagem é limitada, quando tenta definir Deus: "Deus é o mistério sobre o qual nada se pode falar. Ele está além da palavra. O que temos é um horizonte inominável. Idolatria é pretender capturar o inominável numa gaiola de palavras para, assim, dominá-lo, torná-lo previsível" (ALVES, 2015, p. 77). Nessa direção, Rubem Alves diz: "Deus nos deu asas do pensamento para voar, os homens nos deram as gaiolas da religião" (ALVES, 2015, p. 83). É por isso que ele afirma que "Deus não é um objeto de pensamento. É objeto de degustação. Provai e vede que Deus tem gosto bom..." (ALVES, 2015, p. 81). Deus passa a ser experimentado, como uma experiência mística.

Angelus Silesius (1624-1627), místico cristão, filósofo e poeta, dizia que Deus tem, desde o princípio dos tempos, enunciado apenas uma só palavra onde toda a realidade estaria contida. Para ele:

O ruido das vožes bumanas, tão misteriosamente diversas e mutuamente desconcertantes, barra o som do Logos. Não há outro acesso salvo o silencio. Assim, para Silesius, são as pessoas surdas e mudas que estão, dentre todos os seres humanos, mais próximos da fala do Éden (STEINER, 2005, p. 90; grifos do autor).

Semelhantemente, para Rubem Alves: "é preciso fazer calar as palavras para se ver com clareza” (ALVES, 2014, p. 174), em outras palavras: "os místicos e os poetas sabem que o silêncio é nossa morada original" (ALVES, 2003, p. 46). Numa perspectiva linguística de tendência mística, o mundo é como uma concatenação de sílabas secretas, como um idioma absoluto ou de uma letra cósmica, alfa e álefe. Poeticamente, como sugere Borges, no conto As ruinas circulares (1972), a nossa existência pode ser fruto do sonho de outrem. Ainda mais: a linguagem pode ter criado o ser humano e não o ser humano a linguagem.

Rubem Alves compara a linguagem a uma aranha que tece sua teia. No momento preciso e oportuno, ela salta sobre um abismo e um universo começa a ser criado. Assim é a palavra que nasce, que brota do abismo do silêncio. A Palavra primordial, que dá origem a todas as outras:

Mas há uma palavra que brota do silêncio, a Palavra que é o começo do mundo. (...) É fácil distinguir a Palavra das palavras. (...) Mallarmé desejava escrever um livro de uma só palavra. Pensei que ele fosse 
louco... Mas agora, observando a aranha, penso que compreendo: ele desejava capturar a primeira Palavra, que é o início de todas as outras. Esta é a essência da poesia: retornar à Palavra fundadora, gerada no abismo do silêncio (ALVES, 2003, p. 23; grifos do autor).

A tarefa da poesia é traduzir o inefável, se é que isso é possível. Por isso, torna-se a invocação daquilo que está ausente. Rubem Alves exemplifica essa dinâmica da palavra, recriando um novo prólogo para o Evangelho de João:

Cristologia: um poema que se recita diante do Vaz̧io. E eu imagino que um novo prólogo para o evangelho de João poderia ser escrito (...)

Antes que todas as coisas existissem

havia o silêncio.

E então, repentinamente,

ex nibilo

uma Palavra foi ouvida,

e o mundo começou...

No vazio, versos,

universos,

“(...) e eles falaram -

Como poetas

Como mágicos,

Como amantes,

Como teólogos,

Porque teologia é a Palavra falada diante do vazio,

Como uma invocação do Ausente...

Moramos no esquecimento (ALVES, 2003, p. 54-55; grifos do autor).

A primeira fase da linguagem é a gênese da poesia e da religião. A poesia está próxima da magia. Isso explica o parentesco dos poetas com os mágicos e feiticeiros.

A linguagem humana esconde mais do que revela e borra mais do que define. Para Steiner:

Cada língua diferente oferece sua própria negação do determinismo. 'O mundo’, diz ela, 'pode ser outro’. A ambigüidade, a polissemia, a opacidade, a violação das seqüências lógicas e gramaticais, as incompreensões recíprocas, a capacidade para mentir - isso tudo não constitui patologias da linguagem, mas as bases de seus poderes. Sem elas, teriam fenecido o indivíduo e a espécie (STEINER, 2005, p. 254; grifos do autor). 
Rubem Alves concorda com Steiner, em certa medida. Como exemplo, pode-se destacar a história do morto afogado que chega a uma pacata vila de pescadores $^{1}$ e muda a rotina daquele lugar. Ao redor do desconhecido, vão surgindo as mais variadas e ricas narrativas. Contudo, esse momento criativo, polissêmico e desordenado é interrompido por um grupo "iluminado". O objetivo do seleto grupo era trazer "a luz" onde se encontrava a "escuridão" e a "obscuridade". Assim, "libertaram" os sentidos equívocos por sentidos unívocos, transformaram a poesia em prosa e, então, revelaram a "verdadeira" e a "real" história daquele homem que jazia morto na praia. O afogado tornara-se um enigma que acabara de ser decifrado. Os feitos desses heróis foram escritos, como uma fonte documental, com detalhes, categorias e narrativas convincentes e muito bem explicadas, sem ruídos, sem opacidade, com muita lógica e coesão. Só que o fim da história é trágico e triste. Os moradores se convenceram que aquela era a verdadeira e a "correta interpretação" acerca do morto. Então, eles não se lembraram mais das histórias que costumavam contar. Elas caíram no esquecimento. Todos foram dormir, mas não sonharam... A aldeia voltou a ser o que sempre tinha sido, antes da visita daquele estranho corpo afogado. "Acender a luz na sombra destrói a sombra. Conviver com a obscuridade é importante" (ALVES, 2015, p. 292). Os "iluminados" trouxeram lâmpadas em uma das mãos, na outra, estavam os pássaros engaiolados. "Na poesia, os pássaros explodem a gaiola que os prende, e voam levando-nos em suas asas" (ALVES, 2003, p. 133).

Por meio dessa ficção, Rubem Alves critica a tradição teológica e científica. Mas, pode-se pensar também que o que ocorreu foi uma transição da primeira fase, metafórica poética, para a segunda fase, pautada pela racionalização:

A teologia protestante nasceu quando o poder mágico-poético da Palavra foi redescoberto e democratizado. Cada indivíduo deveria ler as escrituras da mesma forma como se lê um poema, na solidão, sem vozes intermediárias de interpretação. (...) Mas logo as exigências do poder perceberam que a liberdade do Vento é perigosa, porque ele sopra onde quer e não onde nós queremos. (...) imagens se transformaram em dogmas, metáforas tomaram a forma de doutrinas, a poesia foi reescrita como "confissões". (...) Em oposição à liberdade selvagem da palavra poética, o protestantismo inaugurou um programa hermenêutico que tem por objetivo preencher todos os espaços vazios [lacunas] onde a voz do Estranho pode ser ouvida. (...) O que está em jogo é a 'redução do sentido

Primeira parte do livro Lições de Feitiçaria: Meditações sobre a poesia. Rubem Alves recria essa narrativa, a partir do conto "O afogado mais bonito do mundo", de Gabriel García Marquez. 
a um único sentido', a transformação da poesia em prosa: essa é a gênese da teologia científica. Uma vez terminado o trabalho, uma vez preenchidos todos os vazios com o conhecimento, descobrimos que a Palavra perdeu seu poder para ressuscitar os mortos (ALVES, 2003, p. 134-135; grifos do autor).

Muitas vezes, a linguagem é pensada como "informação", mas as descontinuidades criativas da primeira fase, as desinformações, a confusão e os múltiplos sentidos são os elementos que a tornam rica e poética. Rubem Alves assim descreve seu texto e sua própria escrita: "Meu texto é habitado por metáforas equívocas, neblinas, imprecisões, jogos de palavras, humor, saltos, repetiçoes. Mas essas são coisas proibidas pelas regras da linguagem do 'País dos Saberes"' (ALVES, 2014, p. 21; grifos do autor).

A espécie humana sobreviveu por causa das ficções, por acreditar que o mundo poderia ser contado de outra maneira:

A linguagem é o principal meio de que dispõe o ser humano para se recusar a aceitar o mundo como ele é. (...) Temos a capacidade, a necessidade de refutar, de 'des-dizer' o mundo, de imaginá-lo e dizê-lo [e por que não, criá-los?] de outros modos (STEINER, 2005, p. 238).

Steiner (2005) sugere que, pela linguagem, é possível criar outros mundos, outras realidades. Rubem Alves, criticando os adeptos da ciência, dirá que eles "não perceberam que as palavras podem ser matéria-prima com que se constroem mundos" (ALVES, 1992, p. 57; grifos do autor). Para Iser (1990), as ficções não são o lado irreal do real, o oposto da realidade, mas condições que permitem a produção de mundos, isto é, alcançar o inacessível inventando possibilidades. Para ele, a arte da ficção é uma extensão da humanidade. Assim, a linguagem é uma criação constante de mundos alternativos. A frase de T. S. Eliot de que a humanidade não pode suportar muita realidade parece corroborar com tal perspectiva. Por não suportar o mundo "real", o ser humano cria mundos alternativos, por meio das ficções. No processo criativo da ficção, é possível estar no mundo e fora do mundo, simultaneamente.

Fingir, cujo significado etimológico está relacionado com "modelar" (fingere em latim), é a capacidade de dizer ou criar coisas que não existem. Em outras palavras, o que não existia passa a existir, por meio da palavra, da ficção:

Só vamos enxergar mais profundamente quando nos livrarmos de uma classificação puramente negativa da 'não-verdade', somente quando reconhecermos 
como central à linguagem e à mente a compulsão para dizer 'o estado de coisas que não existe'. Vamos ter de apreender o que Nietzsche quis dizer quando proclamou que 'A Mentira - e não a Verdade - é divina!' (STEINER, 2005, p. 241; grifos do autor).

Para Rubem Alves, magia é o poder de transformar o sonho em realidade, de criar o inexistente: "Todo artista é um mágico, um feiticeiro" (ALVES, 2014, p. 164). Para ele: "Alimentamo-nos com ficções. Embriagamo-nos com ficções. Fazemos amor com ficções. Ficamos grávidos com ficções” (ALVES, 2014, p. 176).

A religião está imersa na linguagem e na ficção. A experiência religiosa está presente na primeira fase da linguagem. A doutrina, os dogmas, as sistematizações e as estruturas institucionais são fruto da segunda fase. A riqueza da religião não está, necessariamente, na sua historicidade e na seriedade de uma linguagem científica e racional, "baseada em fatos reais", mas nas possibilidades narrativas que dela nascem:

As estórias que contaram sobre o morto não eram sobre o morto. Como poderiam contar estórias sobre alguém que nunca haviam visto antes? As estórias sobre o morto eram histórias sobre eles mesmos. Estórias, não sobre aquilo que eles eram (isso, eles podiam ver nos espelhos), mas estórias sobre seus desejos. (...) Como poderia eu lhe explicar que aquela estória se repetia sempre justamente por nunca haver acontecido no passado, na terra distante? É preciso que nunca tenha acontecido para que possa acontecer sempre... (ALVES, 2003, p. 63; grifos do autor).

Rubem Alves, nessa citação, dá uma indicação do cronotopo² (tempo/ espaço) de uma narrativa mítica ou ficcional: "As estórias têm poder porque nelas o tempo passado e o espaço distante são metáforas do aqui e do agora. Elas nunca aconteceram para que possam acontecer sempre, em todos os lugares" (ALVES, 2003, p. 103; grifos do autor). Agostinho dizia que o tempo é sempre presente: o presente do passado e o presente do futuro. Há uma dualidade de relação pela qual "a linguagem ocorre no tempo, mas também cria, extensivamente, o tempo no qual ela ocorre” (STEINER, 2005, p. 164).

2 Conceito apresentado por: BAKHTIN, M. "Formas de Tempo e de Cronotopo no Romance: Ensaios de poética histórica. In: Questões de Literatura e Estética (A Teoria do Romance), 6. ed. São Paulo: Hucitec, 2012, p. 211-362. 
A teopoética proposta por Rubem Alves revela que os poetas são religiosos que não precisam de religião. As palavras poéticas não estão sujeitas à História e ao tempo, são eternas, como a temporalidade mítica: "A 'história' é uma criatura do tempo. As 'estórias' são emissárias da eternidade" (ALVES, 2015, p. 23). Nesse sentido, Rubem Alves cita Guimarães Rosa: "A estória não quer ser história. A estória, em rigor, deve ser contra a História”.

A partir dos pressupostos vistos até o momento, concernentes à linguagem, torna-se possível uma crítica que se estende também à religião:

O fundamentalismo se revela na linguagem. Ela não tem reticências nem pontos de interrogação. Só pontos finais e pontos de exclamação. Com ela não se pode escrever poemas. Porque os poemas vivem dos silêncios que há nos interstícios das palavras (ALVES, 2015, p. 146).

Rubem Alves caminha na direção oposta ao fundamentalismo, pois destaca o valor da palavra livre, polissêmica, polifônica, incapaz de ficar aprisionada nas amarras do sentido único. Para ele, a religião está no âmbito da poesia, na primeira fase, e não pode ser reduzida à ciência e à razão. Assim, em alguns momentos, suas palavras são ácidas: "Todo poema interpretado literalmente é ridículo. Toda religião que pretenda ter conhecimento científico sobre o mundo é ridícula" (ALVES, 2015, p. 232).

\section{Palavra que se come - presença e eucaristia}

Eucaristia é antropofagia.

- Rubem Alves

Gumbrecht (2006) é um autor alemão que trabalha o conceito de presença na linguagem. Nos primórdios, na oralidade, na poesia, no rito e no mito, a linguagem estava associada a uma realidade física/mágica que tem forma e ritmo. A palavra tinha: "a capacidade de fazer coisas ausentes tornarem-se presentes e coisas presentes tornarem-se ausentes" (GUMBRECHT, 2006, p. 14). Essa mesma capacidade era também a expectativa associada aos encantamentos medievais. O mistério da transubstanciação exemplifica o que se entende por presença, na visão desse autor:

Receber a comunhão, comer o corpo de Cristo era (...) [na] teologia católica nada menos que teofagia. Mas, com a progressiva substituição, na teologia 
da Reforma, da distinção Aristotélica entre 'substância' (o corpo de Cristo) e 'forma' (pão), pela distinção que está implícita no conceito moderno do signo entre "significante" (pão) e "significado" (o conceito do corpo de Cristo), o sacramento da eucaristia mudou de uma cena mágica de evocação do passado, para uma situação de comemoração - uma situação de comemoração que, mais precisamente, implica um distanciamento 'histórico' intransponível entre passado e presente (GUMBRECHT, 2006, p. 17, grifos do autor).

Para Gumbrecht (2006), uma das riquezas da linguagem é que ela pode produzir epifanias, nas quais o passado se torna presente. A eucaristia é um exemplo da transição que ocorreu: de um ritual mágico, ${ }^{3}$ de invocação e presença, passou a ser vista por alguns reformadores apenas como símbolo, memória ou comemoração:

A celebração da missa (...) era um ritual por meio do qual a 'verdadeira' última Ceia [produção da Verdadeira Presença de Deus na Terra entre os vivos] e, acima de tudo, o corpo de Cristo e o sangue de Cristo poderiam tornar-se 'realmente' e de novo presentes (GUMBRECHT,2010, p. 51).

A partir dessa citação, entende-se que a presença se dá na primeira fase da linguagem. O potencial dessa linguagem metafórica é que ela não remete para além dela, mas é concreta. Assim, o pão e o vinho não são símbolos, mas são, realmente, o corpo e o sangue. Pão é corpo e vinho é sangue. Entretanto, cada vez mais o "é" na expressão "este é o meu corpo" (metáfora) passou a ser entendido como "significa" ou "quer dizer" o meu corpo. $\mathrm{Na}$ teologia protestante, as substâncias do pão e do vinho foram substituídas pelo corpo e sangue como sentido. Portanto, ocorreu uma transição da cultura de presença para a cultura de sentido. Para dizer de outra maneira, ocorreu a quebra do feitiço, a racionalização, a transição da primeira fase, metafórico poética, para a segunda fase, metonímica e analógica. $\mathrm{Na}$ cosmovisão moderna, os signos se distanciam no tempo e no espaço daquilo que evocam. No ato da comunhão, na cultura de presença, não se distinguiam os tempos. Passado, presente e futuro se tornavam todos em um só.

Semelhantemente, Rubem Alves diz que a eucaristia é uma metamorfose alquímica, pois as substâncias são transformadas: o pão em carne e o vinho em sangue. Portanto, eucaristia é antropofagia, mais especificamente, teofagia.

\footnotetext{
3 A magia pode ser entendida como uma prática que presentifica coisas que estão ausentes e ausenta coisas que estão presentes.
} 
Aquele/a que come o pão e bebe o vinho, come a carne e bebe o sangue. "Nietzsche e Guimarães Rosa falam sobre uma alquimia parecida em que o sangue é transformado em palavra. Quem lê bebe o sangue de quem escreveu. O ritual da leitura é, como a eucaristia, uma refeição antropofágica" (ALVES, 2015, p. 39, grifos do autor). O poeta Murilo Mendes conhecia essa magia: "No tempo em que eu não era antropófago, isto é, no tempo em que eu não devorava livros - e os livros não são homens, não contêm a substância, o próprio sangue do homem?” (MENDES, A idade do serrote, 1968 apud ALVES, 2014, p. 39).

Na eucaristia, é possível "comer" tanto Deus/Cristo como as palavras, pois se tratam da mesma coisa. "Os próprios textos sagrados (...) dizem que Deus é Palavra: a palavra tem os atributos da divindade" (ALVES, 2014, p. 39). Por intermédio de alguns textos bíblicos, é possível afirmar a igualdade corpo=palavra. Por exemplo, no início do Evangelho de João: “...e a Palavra se fez carne", entre outras possibilidades, a encarnação do Cristo pode ser descrita como a transformação da palavra em corpo.

Nos rituais antropofágicos, as virtudes do morto são transmitidas para o corpo dos vivos. Os/as convidados/as comem o corpo de uma pessoa morta, para serem semelhantes a ela. Como na eucaristia: "o sangue de Cristo é bebido e a sua carne é comida para que a vida que nele havia se transfigure para aquele que comeu sua carne e bebeu o seu sangue" (ALVES, 2014, p. 40, grifos do autor). O texto bíblico de João diz assim: "Porque a minha carne verdadeiramente é comida, e o meu sangue verdadeiramente é bebida. Quem come a minha carne e bebe o meu sangue permanece em mim e eu nele" (João 6.55-56).

Rubem Alves dá detalhes desse processo alquímico, mágico e antropofágico. A ordem natural e normal seria a seguinte: comemos o alimento. $\mathrm{Na}$ antropofagia, ocorre a inversão: somos comidos pela comida. Portanto, na eucaristia:

É a comida (e não os participantes) que executa a transformação alquímica. Se a carne e o sangue da vítima foram assimilados a nosso corpo, eles se tornarão o que somos, e nós permaneceremos os mesmos. Mas se, ao contrário, a carne e o sangue nos devorarem e nos assimilarem, ficaremos semelhantes a eles: o corpo e o sangue de Cristo (ALVES, 2003, p. 36).

Tanto no livro Variações sobre o Prazerer (2014) quanto no livro Lições de Feitiçaria: meditações sobre a poesia (2003), Alves comenta acerca da cozinheira Babette, do filme A Festa de Babette. ${ }^{4} \mathrm{~A}$ incrível cozinheira é metáfora da euca-

4 Ano do filme: 1987 (Dinamarca) - Direção: Gabriel Axel. O livro com o mesmo nome foi escrito por Karen Blixen. 
ristia, pois permite ser "degustada" pelos outros, em um delicioso banquete. O saber da cozinha é também um sabor mágico de presença. "Cozinhar é a arte de tornar real o que é irreal, de tornar presente o que está ausente" (ALVES, 2003, p. 110, grifos do autor).

As duas irmãs beatas, ao saberem que Babette tinha ganhado um bilhete na loteria, já se prepararam para a partida dela, de volta à França. Mas Babette surpreende com um incrível banquete, presentificando o seu passado. Ela não precisou voltar à França. Por meio da "feitiçaria" do cozinhar, a França veio até ela. Naquele fogão, com todos aqueles exóticos ingredientes, ela voltou a ser a grande chef de um sofisticado restaurante francês. Aos convidados/as não restou nada além da graça e do prazer daquele momento/instante divino e kairótico:

O preparo de uma comida é um ritual mágico de repetição do passado. A cozinheira está sempre 'em busca do tempo perdido...' (...) Quero que vocês sintam o prazer e a alegria que moram na minha carne e no meu sangue, para que jamais se esqueçam de mim!. (...) Um banquete sacramental (ALVES, 2014, p. 162-163, grifos do autor).

Seu próprio corpo foi oferecido como comida aos convidados. Por algumas horas, o Paraíso volta e se fazpresente. Além de comida, Babette foi feiticeira, pois transformou um sonho ou um desejo em realidade.

Cozinhar é também um ato criador - o cozinheiro/a cria por meio da comida. Rubem Alves parodia o texto bíblico de Gênesis 1, com certo humor e liberdade:

No princípio era a comida... (...)

Como começou?

No Princípio a cozinha estava escura e vazia...

O fogo apagado, as panelas nos seus lugares, as matérias-primas guardadas. Nada sugere que algo esteja sendo preparado.

Mas, enquanto a cozinha descansa, o "espírito da cozinheira flutua sobre o vazio. E ela diz: "Haja uma moqueca! E houve uma moqueca. E todos viram que a moqueca era boa" (ALVES, 2014, p. 160-161).

\section{A beleza - a face visível do sagrado}

Que a palavra teologia seja substituida pela palavra teopoesia: nada de saber, o máximo de beleza.

- Rubem Alves 
O tema da Beleza é apresentado por Rubem Alves numa perspectiva estético-teológica e estético-poética. A transcendência e o Belo se encontram. A Beleza também toca o universo das experiências místicas. Deus, Beleza e Mistério - palavras que contêm um universo em si mesmas.

"A beleza é a face visível de Deus" (ALVES, 2015, p. 30). Se Deus tem uma face visível, essa face é a beleza. Ao se observar a beleza que se manifesta e se mostra no mundo, enxerga-se a Deus. Nesse sentido: “Quem experimenta a beleza está em comunhão com o sagrado” (ALVES, 2015, p. 195).

Referindo-se ao tema da Beleza divina, Bruno Forte (que parece concordar com Rubem Alves) diz: "o teólogo, ao falar de Deus fala da Beleza e ao falar de tudo o que é belo neste mundo, remete continuamente Àquele que é a fonte e a meta de toda beleza (...). O movimento da belez̧a não é senão o movimento do amor" (FORTE, 2006, p. 12-13, grifos do autor). A beleza é um dos nomes divinos. Simeão, o Novo Teólogo (917-1022) faz uma afirmação concernente à Beleza: "Tocado pelo amor e pelo desejo do Senhor, foi, com esperança, ao encalço da primeira e invisível Beleza” (FILOCALIA, 1986, p. 111).

Questionado acerca de sua crença em Deus, Rubem Alves responde: "Uns acham que eu não acredito em Deus. Como não acreditar em Deus se há jardins? Um jardim é a face visível de Deus. E essa face me basta" (ALVES, 2014, p. 11). Dito de outra forma: “O jardim é a imagem visível da beleza divina" (ALVES, 2003, p. 170). Rubem Alves crê no Deus da beleza, no Deus que dança e que convida pessoas para "brincar" com ele/Ele.

Ao propor uma Teologia da Beleza e da Fruição, ${ }^{5}$ Rubem Alves critica a ausência do elemento estético nas discussões teológicas:

A beleza tem sido a grande ausente do discurso teológico. Insensibilidade estética? Perda da memória do Paraíso? Medo de narcisismo? Teremos, por acaso, separado a bondade da beleza? Será isto que explica a reducão da teologia à ética, seja sob a forma de moral individual, seja sob a forma da teologia política? (ALVES, 2003, p. 171, grifos do autor).

Com a exclusão da beleza no fazer teológico, a teologia ficou reduzida a: 1) uma discussão ética moral individualizada e 2) uma discussão política. Onde estaria a Beleza nessa discussão? Seria a estética desnecessária? Na tentativa de responder a essa importante questão, Rubem Alves utiliza as palavras do

Trata-se de pensamentos acerca do tema. Por teologia, não se entende uma teologia sistemática e categorizada. 
existencialista russo Nikolas Berdjaev: "no Paraíso não existe nem ética nem política; somente estética" (Apud ALVES, 2014, p. 110, grifos do autor). Berdjaev é citado por Rubem Alves em outros momentos. Um deles é acerca do Reino de Deus: "O Reino de Deus só pode ser pensado como um reino de beleza. $A$ transfiguração do mundo é um fenômeno de beleza. E toda a beleza no mundo é ou uma lembrança do paraíso ou uma profecia de um mundo transfigurado" (BERDJAEV, 1965, p. 319, apud ALVES, 2003, p. 172, grifos do autor).

A conhecida frase: "a beleza salvará o mundo", citada no romance "O Idiota", de Dostoiévski, em certa medida, anuncia uma transfiguração do mundo. Não se trata, unicamente, de uma apologia à arte, mas traz uma dimensão de salvação estética, que passa pela beleza. Em termos teológicos, pode-se falar de uma teurgia. A palavra teurgia é grega e provém de theoi, "Deuses", e ergon, "obra”, significando "Obra de Deus/Deuses". Nesse caso, pode-se referir a uma belez̧a presente na Criação. Há uma busca pela divinização do mundo. O ser humano também se torna colaborador ativo da revelação da glória de Deus/Sagrado, como uma expressão de amor ao Amor. Assim, pode-se associar a beleza à salvação do mundo.

O paraíso perdido é memória e profecia escritas nos corpos humanos: "Vocês se lembram que eu comparei o corpo a um palimpsesto. O que está escrito em nossa carne, com caracteres invisíveis, é uma memória e uma profecia do Paraíso" (ALVES, 2003, p. 175).

A beleza é também dialética, pois ela pode ser tanto terrivel como misteriosa. Rubem Alves, continua citando Berdjaev:

Mas o Diabo é também um esteta. 'A beleza tem sua própria dialética', diz Berdjaev, 'e Dostoievski tem algo a dizer sobre o assunto. Ele pensava que a beleza haveria de salvar o mundo. Mas ele diz também: 'A beleza não é apenas uma coisa terrivel e misteriosa. Nela o diabo luta com Deus, e o campo de batalha é o coração humano'. O diabo deseja usar a beleza para os seus próprios fins (BERDJAEV, 1965, p. 319-320, apud ALVES, 2003, p. 176).

Há um elemento trágico na beleza. Rubem Alves dirá que o corpo é como um berimbau, no qual há uma corda tensionada por um arco. A corda é metáfora da vida e o arco da morte. A beleza mora no coração, centro do corpo. Vida e morte se casam e daí nasce a beleza. É por isso que a beleza está misturada com a tristeza. "A beleza é o triunfo da Vida contra a Morte. Ela é a melodia que a vida toca diante do Abismo" (ALVES, 2003, p. 177). É possível contemplar e admirar a beleza, sem ser destruído por ela. Contudo, a 
aproximação da Beleza pode ser muito perigosa. O motivo é que ela faz uso do inimigo e transforma a Morte numa aliada. Rubem Alves não compreende essa luta ou "campo de batalha" numa perspectiva simplista e dualista, mas como uma tensão trágica e dialética da beleza, numa disputa entre a vida e a morte:

Mas o Adversário, o Demônio, o Testador, também se deleita em tocar o berimbau. Mas ele não deseja que o cantus firmus seja ouvido. Ele deseja quebrar a corda. O corpo humano se torna, então, o campo de batalha entre Deus e o Diabo. Como se os dois fossem cúmplices do mesmo jogo. Deus permite que o Testador tencione o arco até seus limites máximos. Deus aposta que Eros haverá de triunfar. Mas o Diabo aposta na Morte. (...) Coisa terrível é encarar a Morte e, a despeito de tudo, continuar a fazer soar o cantus firmus da beleza... (ALVES, 2003, p. 177, 178, 179).

A tragicidade da beleza é algo presente em Dostoiévski, que será retomado por Berdjaev e Rubem Alves. A beleza não elimina a tragédia, mas a torna suportável e até mesmo, necessária. "Quero uma teologia que esteja mais próxima da beleza do que da verdade, porque da visão da beleza surgem os amantes, mas com a verdade se acendem fogueiras" (ALVES, 2015, p. 201, grifos do autor).

Rubem Alves acredita que as outras faces da beleza, o mistério e a Vida estão presentes, entre outras possibilidades, nas palavras de esperança dos profetas. "E se ouve então, no deserto da Morte, a canção do profeta" (ALVES, 2003 , p. 179). Que palavra ou canção tem o poder de trazer de volta à vida aquilo que a morte ceifou? Efetivamente, o profeta não canta a canção fúnebre, ao contrário, ele subverte o funeral. "O Diabo toca a marcha fúnebre com o berimbau de corda arrebentada. O profeta assobia uma canção de ninar" (ALVES, 2003, p. 179). Rubem Alves menciona o episódio do profeta Ezequiel no Vale de Ossos Secos. O profeta voa com o Vento gerador de vida: "Assim diz o Senhor Deus: Vem dos quatro ventos, ó espírito, e assopra sobre estes mortos, para que vivam" (Ezequiel 37.9, grifos do autor). Para exemplificar o poder da vida sobre a morte, Rubem Alves conta a seguinte narrativa:

Numa sepultura próxima, uma jovem mulher deu à luz um menino. O velho coveiro de oitenta anos, enrolado numa toalha de linho, ajudava. Quando o menino deu seu primeiro grito, o velho homem orou: "Grande Deus, finalmente nos enviaste o Messias! Pois que outra criança, a não ser o próprio Messias, poderia nascer numa sepultura?" O nome deste evento misterioso é "Beleza": quando a vida, suave e frágil, doce e vazia de qualquer mal, nasce 
de sepultura. O poeta que escreveu esse poema era o profeta que pregava aos ossos secos espalhados no vale (ALVES, 2003, p. 186, grifo do autor).

Pensar Deus a partir da beleza tangencia o tema da teologia mística. Rubem Alves se expressa, em alguns momentos, como um místico. Ele entende que a experiência mística não diz respeito ao sobrenatural, aos seres de outro mundo, mas "é ver este mundo iluminado pela beleza..." (ALVES, 2015, p. 62, grifos do autor). Ele compara Deus ao ar: quando se está em uma boa relação com ele/Ele, não se fala nada. Mas, quando falta o ar, como um ataque de asma, então é preciso "gritar" por Deus. Assim, "quem pensa demais e fala demais sobre Deus é porque não o está respirando" (ALVES, 2015, p. 196). O misticismo ou a espiritualidade proposta por Alves é bastante imanente, com destaque para a "beleza" presente nas coisas mais simples e cotidianas da vida:

Sou místico. Ao contrário dos místicos religiosos, que fecham os olhos para verem Deus, a Virgem e os anjos, eu abro bem os meus olhos para ver as frutas e legumes nas bancas de feira. Cada fruta é um assombro, um milagre. Uma cebola é um milagre (ALVES, 2015, p. 222).

Por esse motivo, não deixa de criticar as tradições teológicas que tendem a negar o mundo, de maneira escapista: "Vejo as pessoas religiosas fecharem os olhos para orar. Elas creem que, para se ver Deus, é preciso não ver o mundo. Elas não sabem que a beleza da natureza é o espelho onde Deus se contempla" (ALVES, 2015, p. 243, grifos do autor). Não seria exagero dizer que a mística que ele apresenta está muito próxima do conceito de panenteísmo ( pan = totalidade $+e n=\mathrm{em}$, dentro + theismus $=$ teísmo, Deus $)-$ ideia de que Deus ou o Sagrado está presente em tudo, em cada ser da natureza. Por isso: "tudo que vive é pulsação do sagrado. As aves dos céus, os lírios dos campos. Até o mais insignificante grilo no seu cri cri cri rítmico, é uma música do Grande Mistério" (ALVES, 2015, p. 234, grifos do autor).

Até o momento foi explorada a perspectiva estética-teológica, a seguir será tratada, mais brevemente, a perspectiva estética-poética.

Para Rubem Alves: "A beleza é algo que cresce solitariamente dentro do corpo do artista, como uma gravidez!” (ALVES, 2003, p. 148). A beleza é gerada pelo artista. O artista dá a luz à beleza. Para ele, a beleza é alimento da alma, ela é leve: 
Alma não come pão. Alma come beleza. O pão engorda, faz o corpo ficar pesado. A beleza, ao contrário, faz a gente ficar cada vez mais leve. Não é raro que os comedores de beleza se tornem criaturas aladas e desapareçam no azul do céu (...). A beleźa é coisa da leveza (ALVES, 2015, p. 56, grifos do autor).

O compromisso do poeta é com a beleza. Ele (ou a poetisa) é livre e não pode estar preso a qualquer amarra ideológica ou partidária. A poesia e a beleza não podem ser instrumentalizadas. Poeta não é propagandista. Reduzi-lo a essa tarefa seria humilhante. Nesse sentido, Rubem Alves faz uma observação que é também uma provocação:

Parece que essa foi uma das razões para o suicídio de Maiakovski [a utilização indevida de sua arte]. O partido exigia que sua poesia fosse usada para inculcar a ideologia, mas sua alma estava comprometida com a belez̧a. Compreende-se, portanto, que Guimarães Rosa tivesse os políticos em tão baixa conta. Numa entrevista de janeiro de 1965 ele [Guimarães Rosa] diz: "Os políticos estão sempre falando em lógica, razão, realidade e outras coisas do gênero e ao mesmo tempo vão praticando os atos mais irracionais que se possa imaginar. Ao contrário dos "legítimos" políticos, acredito no homem e lhe desejo um futuro. Sou escritor e penso em eternidades. O político pensa penas em minutos. Eu penso na ressurreição do homem" (ROSA, 1983, p. 10, apud ALVES, 2003, p. 146, grifos do autor).

Rubem Alves destaca o potencial e a beleza da palavra poética:

Se o povo não sonha e não tem visões de beleza, não terá desejo de lutar. E me lembro de Lutero dizendo, numa de suas "Conversas de Mesa", que a Reforma não estava sendo feita pelo poder de suas mãos, mas pelo poder da palavra. E num tom de brincadeira diz que, enquanto ele e Melanchton nada faziam, mas simplesmente tomavam cerveja, a palavra ia voando livre, atravessando os campos e as aldeias... O futuro mora na palavra poética que anuncia uma beleza ausente (ALVES, 2003, p. 160, grifos do autor).

Assim como o mito do eterno retorno, a beleza precisa ser repetida. A cada repetição, uma ressurreição. Sempre o mesmo, nunca o mesmo... "Por oposição ao tempo cronológico, tempo do 'nunca mais', que devora seus filhos, o tempo da beleza é sagrado, tempo da ressurreição que renasce a cada manhã" (ALVES, 2003, p. 64, grifos do autor).

Após quarenta dias sem comer nada, em jejum, Cristo foi tentado. Foi oferecido a Ele o pão que mata a fome e alimenta o corpo. Contudo, Ele 
recusa a oferta do Tentador, respondendo: "Nem só de pão viverá o homem, mas de toda a palavra que sai da boca de Deus" (Mateus 4.4, grifos do autor). Aqui, o alimento que satisfaz é a palavra e não o pão. É a palavra que permite sonhos de beleza:

É isto que os homens de pensamento, nas universidades e nos partidos, não poderiam nunca entender: que mesmo os famintos não sobrevivem só de pão. (...) Os sonhos não se fazem só com pão e poder. Existe um sonho mais profundo e imortal: o sonho da beleza (ALVES, 2003, p. 156-157, grifos do autor).

Essa citação traz à memória um conto de Dostoiévski, chamado O Grande Inquisidor. ${ }^{6} \mathrm{O}$ próprio Rubem Alves menciona esse importante texto. Nesse conto, Jesus retorna à Terra, na Sevilha do século XVI, em meio à inquisição espanhola. Ele é condenado como herege pelo cardeal, o grande inquisidor. As acusações feitas a Cristo são: 1) ter concedido liberdade ao ser humano; 2) ter recusado as três tentações, o pão, o milagre e o poder, oferecidos pelo Diabo, no deserto. O conto/poema problematiza alguns temas. Contudo, o que se deseja destacar aqui é a negação do pão feita por Cristo, já citada. À semelhança do Cristo bíblico, o Cristo de Dostoiévski sabia que pão algum poderia satisfazer sua fome: "Ele tinha fome de um pão ausente cuja única evidência era uma Palavra" (ALVES, 2003, p. 109, grifo do autor). A escolha feita pelo Cristo dostoievskiano horrorizou o inquisidor: "Mas é precisamente essa liberdade da palavra poética que horroriza o poder. O Grande Inquisidor condenou o Verbo à morte a fim de manter suas muitas palavras na prisão. Os inquisidores sempre condenam a Palavra ao silêncio..." (ALVES, 2003, p. 134, grifos do autor).

\section{Considerações finais}

No coração do processo criativo, há um paradoxo religioso. Nenhum homem é mais inteiramente lavrado à imagem e semelhança de Deus ou mais inevitavelmente do que Seu desafiante, o poeta.

- George Steiner

Rubem Alves sabia que Deus é poeta. Ele também sabia que a obraprima da criação divina, o ser humano, também foi dotada de uma capacidade criativa e poética. Em teologia, o tema da imago Dei, ou imagem de Deus, é

6 $\quad$ Esse conto é parte do romance “Os Irmãos Karamázov” (1878-1880). 
bastante explorado. No caso da teopoética de Rubem Alves, o elo comum que se destaca entre o divino e o humano é a poesia. Deus pensado como Beleza, como artista, como Criador, como escritor. Essa mesma capacidade divina é transmitida aos seres humanos mortais.

Em linhas gerais, este artigo procurou demonstrar e aproximar a relação poética existente entre o Sagrado e o humano. Nessa perspectiva, Deus e a religião não estão classificados como um conjunto de doutrinas, normas, tradições ou confessionalidades, mas como Palavra livre, que venta onde quer e como quer. A liberdade da Palavra, a partir de Rubem Alves, permitiu aproximações com alguns autores acerca dos temas da linguagem, da ficção, da literatura, da beleza, da estética, e por que não dizer, das experiências sagradas.

O Rubem Alves tardio, das muitas fábulas e histórias, problematiza temas complexos, por meio de uma forma literária e narrativa que, muitas vezes, pode ser subestimada ou criticada como "não acadêmica". Mas essa "liberdade criativa" e não muito sistemática contém um universo e uma riqueza que precisam ser melhor explorados. Assim, este artigo, nada conclusivo, teve a intenção de ser um "aperitivo" ou uma "entrada", ou ainda uma "receita" ou um "mapa". Cabe ao leitor/a, a partir dele, aventurar-se e se perder com as palavras.

\section{Referências}

AgostinHO. Confissões. Petrópolis: Vozes, 2001.

ALVES, Rubem. O que é religião. São Paulo: Brasiliense, 1992, 15. ed.

ALVES, Rubem. A Festa de Maria, 7. ed. Campinas, SP: Papirus, 2003.

ALVES, Rubem. Lições de Feitiçaria: meditações sobre a poesia. São Paulo: Loyola, 2003.

ALVES, Rubem. Variações sobre o prazer, 2. ed. São Paulo: Planeta, 2014.

ALVES, Rubem. Rubem Alves essencial: $\mathbf{3 0 0}$ pílulas de sabedoria, 1. ed. São Paulo: Planeta, 2015.

BAKHTIN, Mikhail. "Forms of Time and of the Chronotope in the Novel." In: The Dialogic Imagination. Four Essays. Austin: University of Texas Press, 1981, p. 84-151.

BAKHTIN, Mikhail. Questões de Literatura e Estética (A Teoria do Romance). Equipe de tradução (do russo): Aurora Fornoni Bernardini, José Pereira Júnior, Augusto Góes Júnior, Helena Spryndis Nazário, Homero Freitas de Andrade, 6. ed. São Paulo: Hucitec, 2012.

BERDiAefF, N. O Espírito de Dostoiévski. Trad. de Otto Schneider. Rio de Janeiro: Panamericana, 1921.

BERDJAEV, Nicolai. Christian Existentialism. New York: Harper \& Row, 1965.

BORGES, Jorge Luis. Ficções. Tradução de Carlos Nejar, 1. ed. São Paulo: Abril Cultural, 1972. 
DOSTOIÉVSKI, F. M. O Idiota. Tradução de Paulo Bezerra e desenhos de Oswaldo Goeldi. São Paulo: Editora 34, 2002. Coleção Leste.

DOSTOIÉVSKI, F. M. Os irmãos Karamázov. Tradução de Rachel de Queiroz. Rio de Janeiro: José Olympio, 1953.

DOSTOIÉVSKI, F. M. Os irmãos Karamázov. Tradução de Paulo Bezerra e desenhos de Ulysses Bôscolo. São Paulo: Editora 34, 2008, v. 1-2. Coleção Leste.

FORTE, Bruno. A porta da beleza: por uma estética teológica. Tradução de Afonso Paschotte. São Paulo-Aparecida: Idéias e Letras, 2006.

FRYE, Northrop. O Código dos Códigos: a Bíblia e a Literatura. Tradução de Flávio Aguiar. São Paulo: Boitempo, 2004.

GOLIN, Luana Martins. O Reino de Cristo e o Reino do Anticristo: liberdade e autoridade em Dostoiévski. São Paulo: Fonte Editorial, 2012.

GUMBRECHT, Hans Ulrich. "A presença realizada na linguagem: com atenção especial para a presença do passado." Originalmente publicado em inglês. In: History and Theory, 45 (out. 2006), p. 317-327. Tradução de Bruno Diniz e Juliana Jardim de Oliveira, com revisão técnica de Valdei Araújo, p. 10-22.

GUMBRECHT, Hans Ulrich. Produção de Presença: o que o sentido não consegue transmitir. Tradução de Ana Isabel Soares. Rio de Janeiro: Contraponto: Ed. Puc-Rio, 2010.

ISER, Wolfgang. "Fictionalizing: the anthropological dimension of literary fictions." In: New Literary History, v. 21 (1990), p. 939-955. Tradução e notas de Vicente Bernaschina Schürmann.

ISER, Wolfgang. O fictício e o imaginário: perspectivas de uma antropologia literária. Tradução de Johannes Kretschmer, 2. ed. Rio de Janeiro: EdUERJ, 2013.

MENDES, M. A idade do serrote. Rio de Janeiro: Sabiá, 1968.

PEQUENA FILOCALIA: o livro clássico da Igreja oriental. São Paulo: Paulinas, 1986.

ROSA, João Guimarães. “Literatura e Vida.” In: Arte em Revista. São Paulo: Ceac, 1983, ano I, n. 2.

STEINER, George. Depois de Babel - Questões de Linguagem e tradução. Tradução de Carlos Alberto Faraco, 3. ed. Curitiba: UFPR, 2005.

Submetido em: 1-3-2017

Aceito em: 18-7-2017 